\title{
Blood pressure levels and adherence to treatment of hypertensive patients, users of a school pharmacy
}

\author{
Brigitte Rieckmann Martins dos Santos*,, Juliana Teixeira' ${ }^{1}$, Débora Gonçalves ${ }^{1}$, Reynaldo \\ Mascagni Gatti ${ }^{1}$, Boni Yavo ${ }^{1}$, Cicera Cristina Vidal Aragão²
}

\author{
${ }^{1}$ Municipal University of São Caetano do Sul, ${ }^{2}$ School Pharmacy, \\ Municipal University of São Caetano do Sul
}

\begin{abstract}
Adherence to pharmacological treatment for hypertension is considered a key factor in guaranteeing successful therapy outcomes. Knowledge of the disease, its complications, as well as the need for changes in lifestyle, call for patient motivation and continuous interactive education. The evidence regarding the beneficial effects of changes in life style by hypertensive individuals in reducing the complications of the disease, as well as in its prevention are indisputable. However, the challenges posed by patient adherence to treatment prescribed by doctors remain. The aim of this study was to assess blood pressure levels together with degree of adherence to pharmacological treatment with Enalapril Maleate by means of the Morisky-Green Test, in hypertensive patients who were users of a School Pharmacy. Of the 102 patients interviewed, $65.7 \%$ had controlled blood pressure, but only $36.3 \%$ indicated total compliance with the pharmacological treatment. The Morisky-Green test proved ineffective in associating controlled blood pressure levels and positive attitudes toward taking antihypertensive medicines.
\end{abstract}

Uniterms: Adherence. Hypertension. Health Promotion.

\begin{abstract}
A adesão ao tratamento farmacológico da hipertensão arterial sistêmica é considerada uma das etapas essenciais para a garantia do seu sucesso. Para tanto, o conhecimento da doença, suas complicações e necessidade de mudanças em relação ao estilo de vida, requer do paciente, além da motivação, a educação contínua e de modo compartilhado. A evidência quanto aos efeitos benéficos da mudança do estilo de vida pelo portador de hipertensão na redução das complicações desta doença, bem como em sua prevenção, já não são mais questionados, porém o desafio continua residindo na adesão do indivíduo ao padrão de tratamento prescrito pelo médico. Este estudo teve como objetivo avaliar os níveis de pressão arterial, assim como o nível de adesão ao tratamento farmacológico com maleato de enalapril de pacientes portadores de hipertensão arterial, usuários de uma Farmácia Escola, através do Teste de Morisky e Green. Dos 102 pacientes entrevistados, 65,7\% apresentaram níveis pressóricos controlados, porém apenas 36,3\% indicaram níveis de adesão total à terapêutica farmacológica. O teste de Morisky e Green não foi eficiente para relacionar níveis de pressão arterial controlado e atitude positiva frente à tomada do medicamento anti-hipertensivo fornecido.
\end{abstract}

Unitermos: Adesão. Hipertensão arterial sistêmica. Promoção da saúde.

\section{INTRODUCTION}

The change in mortality profile by groups of causes of death as a consequence of the epidemiological transition has led to the emergence of chronic-degenerative

\footnotetext{
Correspondence: Brigitte R. M. Santos. Escola de Saúde, Universidade Municipal de São Caetano do Sul. Rua Santo Antonio, 50 - 09521-050 - São Caetano do Sul - SP, Brasil. E-mail: brigitterie@yahoo.com.br
}

diseases as the leading cause of morbidity and mortality globally, in both developed and developing countries (Omram, 1971). As a result of this phenomenon, a lower incidence of infectious-parasitic diseases and an increase in neoplastic and cardiovascular disease has been observed (Oliveira et al., 2004).

In Brazil, data from 2003 show that $27.4 \%$ of deaths were attributed to cardiovascular diseases, a figure attaining $37 \%$ when excluding deaths of ambiguous or 
violent causes. The leading cause of death throughout the Brazilian territory is stroke, occurring more predominantly in women (Lotufo, 2005). In addition, these diseases were the leading cause of hospitalization in the public sector, accounting for $17 \%$ of hospital admissions to state hospitals between 1996 and 1999 among patients aged between 40 and 59 years, and for $29 \%$ of patients aged 60 years or older (Passos, Assis, Barreto, 2006).

Current trends show a rise in the elderly population and increasing longevity, coupled with changes in eating habits and lifestyles. A repercussion of an aging population is a higher prevalence of chronic diseases such as hypertension (Monego, Jardim, 2006; Passos, Assis, Barreto, 2006; Lieberman, 2007).

High blood pressure represents a linear and continuous independent risk factor for cardiovascular disease because it results in complications including cerebrovascular disease, coronary artery disease, heart failure, chronic renal insufficiency and vascular diseases of the extremities (Lewington et al., 2003). Systemic arterial hypertension is responsible for $40 \%$ of deaths by stroke and $25 \%$ by coronary heart diseases. The prevalence of hypertension ranges between $15 \%$ and $20 \%$ among the adult population and is characterized by high blood pressure (Passos, Assis, Barreto, 2006).

According to the V Guidelines on Arterial Hypertension (2007), patients are considered hypertensive if they have blood pressure greater than 140 and $90 \mathrm{mmHg}$ in terms of systolic and diastolic pressures, respectively. Controlled patients are individuals whose blood pressure is below the levels cited above. Individual characteristics comprise presence of risk factors such as age, high cholesterol levels, smoking, diabetes, hereditary factors, obesity, sedentary lifestyle and lack of physical exercise, stress, consumption of alcoholic beverages, quality of life among others.

Hypertension is managed through continuous use of medications, changes in life habits and regular visits to health services. Non-medicinal approaches such as reducing weight, salt intake, alcohol or tobacco use, and regular practice of physical activities contribute toward controlling pressure levels (Fuchs, Castro, Fuchs, 2004; V Brazilian Guidelines on Arterial Hypertension, 2007). Treatment using medications is adopted when these measures are no longer able to control blood pressure.

However, adherence to prescribed courses of medications and to non-medicinal treatment, which should be prescribed and monitored by a multi-disciplinary team of health professionals during a visit by the patient to the health service, is complex since it involves cultural and socioeconomic aspects and often results in continued or definitive non-compliance with treatment. Studies have shown that rates of abandonment of antihypertensive treatment are high, ranging from $15 \%$ to $50 \%$ within the first year of treatment (Giorgio, 2006; Martino et al., 2008; Vrjens et al., 2008). Despite efforts to diagnose and treat arterial hypertension, between $75 \%$ and $92 \%$ of those undergoing treatment are unable to control blood pressure (Stein et al., 2000; Jo et al., 2001; Gu et al., 2002).

Therefore, the role of a multi-disciplined team of health professionals is important to help promote adherence to drug treatment in patients with poor blood pressure control. Encouraging the patient to adhere to the therapeutic schemes prescribed requires investment by the multiprofessional team of dedication, patience and time to provide the right information and guidance for patient treatment (Giorgio, 2006).

According to Giorgio (2006), ensuring adherence to treatment requires that "the patient must be aware of their state of health, the importance of controlling blood pressure, and of having access to health services, while these services must be able to provide treatment throughout the life of the patient".

Poor adherence to treatment is also recognized as an economic problem because chronic diseases which are not properly treated generate higher costs for the public health system (Lessa, 2006).

The role of multidisciplinary healthcare teams, centered on education as a strategy for promoting health, is aimed at integral care of the patient as well as identifying circumstances which may hamper adherence of hypertensive patients to the indicated treatment. This approach constitutes a means of instilling motivation in patients to overcome the challenges and adopt attitudes toward improving their well being (Fuchs, Castro, Fuchs, 2004; Giorgio, 2006).

Against this background, this study sought to measure blood pressure levels in hypertensive patients who were users of a School Pharmacy, and to assess correlation with level of adherence to pharmacological treatment with Enalapril Maleate by means of the Morisky-Green Test.

\section{MATERIAL AND METHODS}

This was a transverse, descriptive, observational study with a quantitative approach (Gil, 2010). The study sample comprised hypertensive patients who were users of the School Pharmacy of the Municipal University of São Caetano do Sul (USCS), and recruited as volunteers from among those attended at the service. The School Pharmacy is part of the Center for Production, Control and Dispensing of Medicines (CPCDM) associated with the Pharmacy Course of the Municipal University of São 
Caetano do Sul, in partnership with São Caetano do Sul Board of Health. The objective of the service is to cater for the needs of the municipal population through the provision of medicines formulated free of charge in accordance with the medical prescription.

Prior to collecting blood pressure measurements for the study, upper limbs of each individual were checked using the auscultation and aneroid sphygmomanometry technique, duly calibrated to rule out divergent values in blood pressure between the two upper limbs and to determine which limb was to be used for measurements throughout the study. The concept for hypertension described in the V Guidelines on Arterial Hypertension (2007) was adopted, defining hypertension as systolic blood pressure levels (SBP) of greater than or equal to $140 \mathrm{mmHg}$ or diastolic pressure (DBP) of greater than or equal to $90 \mathrm{mmHg}$ on at least two assessments, with an interval of at least two minutes between them. Individuals previously diagnosed with hypertension were considered to have controlled hypertension when presenting an arithmetic mean of two or three blood pressure readings in the upper limb taken in the sitting position, with an interval of five minutes between measurements, of lower than $140 \mathrm{mmHg}$ for SBP and $90 \mathrm{mmHg}$ for DBP. Individuals were deemed uncontrolled hypertensives when presenting mean pressure levels of greater than or equal to $140 \mathrm{mmHg}$ for SBP and $90 \mathrm{mmHg}$ for DBP. Patients considered uncontrolled hypertensives were classified as hypertension level 1,2 or 3, or as having isolated systolic hypertension

Assessment of adherence to drug treatment was performed based on application of the criteria proposed by Morisky and Green (1986). This classification takes into account the following items: going without taking medication for some reason, i.e. includes abidance to the number of medicines and number of doses taken per day; 2 ) attitude to not going without medicine, representing degree of responsibility and commitment to the treatment; 3) frequency of forgetting, corresponding to the number of occasions the time to take medication was forgotten and reveals the degree of commitment to the treatment, but is subject to memory labilility and changes in routine which may contribute to forgetfulness, 4) attitude to forgetting to take the medication, representing the degree of commitment with the treatment, considering the possibility of remedying a mistake made. For each criteria, positive scores are assigned: (1) if a positive attitude by patient is identified, or no score (0), if patient attitude was negative. Patients were divided into three groups based on the results of the analysis of the four criteria: 1) total adherence (four points), 2) partial adherence (two or three points) and 3) no adherence (one or zero points) (Morisky, Green,
Levine, 1986).

The following inclusion criteria were adopted: having hypertension, with diagnosis confirmed according to the clinical criteria proposed by the $\mathrm{V}$ Guidelines on Arterial Hypertension (2007); be aged 18 year or older; be registered at the USCS School Pharmacy for monthly collection of medicine for at least three months; in use of Enalapril Maleate; users agreeing to participate in the study in accordance with the provision in Resolution 196/96 of the National Medical Council (CNS) (1996). Exclusion criteria were: users diagnosed with hypertension younger than 18 years of age; not in use of Enalapril Maleate; women with specific pregnancy-related hypertensive disease, users with chronic, degenerative, debilitating diseases or neurological sequelae or mental disturbances who present limited autonomy and decision-making faculties; and users who did not agree to take part or that dropped out of the study at any point during the research process. The study was conducted between February and June 2008.

The entire research process was conducted in accordance with the ethical principles set forth in Resolution no. 196/96 by the National Medical Council of the Ministry of Health, guaranteeing participants free and informed consent, confidentiality of information and privacy. The study protocol was previously approved by the Research Ethics Committee of Santa Cecilia University - UNISANTA under process no. 55/07.

In addition the questionnaire on adherence to drug treatment, patients were submitted to a structured questionnaire on socioeconomic aspects (age, marital status, schooling), time since hypertension diagnosis, habits regarding tobacco and alcohol use and practice of physical activity. The whole process was pretested by applying it to ten hypertensive users and adapting as needed.

\section{Statistical Analysis}

The data collected was transcribed to an electronic form using the statistical software Statistical Package for the Social Sciences (SPSS for Windows, version 16.0). After data entry to a spreadsheet, exploratory analysis was performed to identify the variables and correct any errors and/or inconsistencies in data collection and entry. Data analysis entailed description of frequencies and performing of tests of association for the variables: blood pressure classification, schooling, time in treatment and level of adherence (Chi-squared test). Continuous variables were expressed as mean and standard deviation and compared using Student's $t$ test. Finally, correlations between level of adherence to drug treatment and blood pressure were ascertained by applying Spearman's correlation coefficient. 
A level of 0.05 (or 5\%) was considered for rejection of the null hypothesis (Hair et al., 2005; Pestana, Gageiro, 2000).

\section{RESULTS}

A total of 110 users of the School Pharmacy with arterial hypertension were interviewed. Eight individuals were excluded from the sample because they had not provided all the information required. Thus, the final sample comprised 102 individuals (53 men and 49 women) with a mean age of 67.1 years, $22.5 \%$ in the 51 to 60 year age bracket and $71.6 \%$ aged older than 61 years (Table I).

Mean disease treatment time was $5.8 \pm 5.7$ years (minimum of three months according to inclusion criteria and maximum of 30 years). A total of $17.6 \%$ of interviewees were undergoing treatment for arterial hypertension for at least 1 year, $26.5 \%$ and $55 \%$ had been receiving treatment from 1 to 3 years and more than three years, respectively. Of the patients with controlled and uncontrolled blood pressure levels, $36.3 \%$ and $22.5 \%$ received Enalapril Maleate, respectively as the sole medication for controlling arterial hypertension. In addition to Enalapril, 16.6\% also received a diuretic (cloran, hydrochlorothiazide, furosemide, chlorthalidone, moduretic) whereas $11.8 \%$, together with Enalapril, received another antihypertensive (athenolol, carvelidol, captopril or losartan) and 10.8\% received, in addition to Enalapril, both a diuretic and another antihypertensive). A total of $54.9 \%$ of interviewees had a low level of schooling, i.e. had not completed Elementary School, and $68.6 \%$ of respondents were married. Mean systolic pressure was $120.2 \pm 8.7 \mathrm{mmHg}$ and $136.0 \pm 15.3 \mathrm{mmHg}$ among individuals with controlled and uncontrolled arterial pressure, respectively $(\mathrm{p} \leq 0.05)$. Levels of diastolic pressure were $76.9 \pm 7.2 \mathrm{mmHg}$ and $88.6 \pm 6.1 \mathrm{mmHg}$ for controlled and uncontrolled cases, respectively $(\mathrm{p} \leq 0.05)$. Of patients with controlled arterial pressure, $36.3 \%$ had total adherence and $29.4 \%$ partial adherence. Among uncontrolled patients, $12.7 \%$ had total adherence and $21.6 \%$ partial adherence, i.e., $51 \%$ of patients were considered non-adherents (score $\leq 3$ ). None of the patients interviewed reported zero adherence. No significant correlation was found between level of adherence and the independent variables.

With regard to the Morisky-Green test (Table II), significant correlation was seen only for the item "did not forget to take the medicine" $(\mathrm{p} \leq 0.05)$. However, patients were found to have a positive attitude toward taking Enalapril Maleate, since $91.2 \%$ stated that they "did not stop taking the medicine when feeling well" and $94.1 \%$ "did not stop taking it when not feeling well". The Morisky-Green test had sensitivity of $55.2 \%$, specificity of $37.1 \%$, and accuracy of $49.0 \%$, indicating that it was ineffective for associating arterial pressure control and positive attitude toward taking Enalapril Maleate.

\section{DISCUSSION}

In the present study, $65.7 \%$ of patients submitted to treatment with Enalapril Maleate, either as the sole medication for controlling arterial hypertension, or in a combined dose with diuretics and/or another antihypertensive, had controlled blood pressure levels, but only $49 \%$ of interviewees reported total adherence to treatment. Previous studies using the Morisky-Green Test have identified adherence levels varying from 13.3\% (DOSSE et al., 2010), 23\% (Strelec, Pierin, Mion, 2003), 48\% (Martino et al., 2008), 56\% (Bovet et al., 2002), to 76.8\% (Pérez et al., 2000). However, the results of this last author were compared with pill count as opposed to blood pressure control. With regard to correlation between adherence to the pharmacological therapy and control of blood pressure, a significant difference was found only for the question "forgot to take the medicine". Khalil, Elzubier (1997) and Bovet et al (2002) described a positive correlation while Strelec, Pierin, Mion (2003) and Wetzels et al (2004) found no significant correlation. According to Bovet (2002), the method of assessing the criteria adapted by the Morisky-Green test is extremely rigorous, given that it allows no manner of carelessness or forgetfulness regarding time to take the medications. However, isolated episodes of forgetting up to once per week are similar to daily use, resulting in a lowering of blood pressures over a twelve-month period.

Another aspect to be considered is the capability of the Morisky-Green Test to detect patients with controlled pressure that adhere to the treatment. In this study the sensitivity of the test was $55.2 \%$. The specificity for identifying non-adherent patients with uncontrolled blood pressure was $37.1 \%$. Accuracy of the test was $49.0 \%$. Strelec, Pierin, Mion (2003) found specificity of 70\%, low sensitivity (39\%) and low accuracy (39\%). Thus, akin to the findings of Strelec, Pierin, Mion (2003) the present study found the Morisky-Green test to be ineffective in associating arterial pressure control and level of adherence to pharmacological treatment.

The fact that patients were dispensed medications free of charge from the School Pharmacy may have had a positive influence on levels of total adherence to treatment, since according to the Pedagogic Project of the Pharmacy Course of the Municipal University of São Caetano do Sul (USCS), there is a concern with training students to be humanistic professionals, who are centered 
TABLE I - Distribution of controlled and uncontrolled hypertensive patients according to sociocultural and disease characteristics.

\begin{tabular}{cccccccc}
\hline & \multicolumn{2}{c}{ Controlled } & \multicolumn{2}{c}{ Uncontrolled } & \multicolumn{2}{c}{ Total } \\
& \multicolumn{2}{c}{$\mathrm{N}=67$} & \multicolumn{2}{c}{$\mathrm{N}=35$} & \multicolumn{2}{c}{$\mathrm{N}=102$} \\
\hline Gender & $\mathrm{N}$ & $(\%)$ & $\mathrm{N}$ & $(\%)$ & $\mathrm{N}$ & $(\%)$ \\
Male & 32 & $(31.4)$ & 21 & $(20.6)$ & 53 & $(52.0)$ \\
Female & 35 & $(34.3)$ & 14 & $(13.7)$ & 49 & $(48.0)$
\end{tabular}

Educational Level

Without schooling

With schooling

41

26

Marital Status

Single

Married

Widow/Widower

Separated

Age Group

$<40$ years

$41-50$

51 to 60

$>60$ years

Time in treatment

$$
\begin{aligned}
& <1 \text { year } \\
& 1 \text { to } 3 \text { years } \\
& >3 \text { years }
\end{aligned}
$$

No. medications prescribed

one

two

$\geq$ three

Medications prescribed for controlling hypertension

Enalapril

Enalapril + diuretic

Enalapril + antihypertensive

Enalapril + diuretic + antihypertensive

Level of Adherence

Total Adherence

Partial Adherence

No Adherence

Blood Pressure Levels

Excellent

Normal

Borderline

Hypertension level 1

Hypertension level 2

Isolated Hypertension.

Age (years)

$\mathrm{N}^{\text {o. }}$ of medications

Systolic blood pressure*

Diastolic blood pressure*

04

49

12

02

02

02

14

49

10

16

36

13

12

11

37

30

10

24

-

$-$

$\begin{array}{llll}(40.2) & 15 & (14.7) & 56 \\ (25.6) & 20 & (19.6) & 46\end{array}$

(3.9)

03

(2.9)

(6.9)

(48.0)

21

(20.6)

07

(68.6)

(11.8)

(7.8)

(2.0)

03

(2.9)

(2.0)

(2.0)

01

(1.0)

(13.7)

(1.0)

(48.0)

09

(8.8)

(22.5)

24

(23.5)

(71.6)

14.9

08

23.9

11

22.9

31.4

45.7

17.6

61.2

16

(35.3)

22

(21.6)

(10.8)

(2.0)

18

27

26.5

55.9

(17.6)

11

(12.7)

02

(56.9)

(36.3)

23

(22.5)

(4.9)

(4.9)

(2.0)

(28.4)

(14.7)

(11.7)

05

(6.9)

05

(10.8)

02

58

29

15

(36.3)

12

(12.7)

(21.6)

60

(58.8)

(16.6)

(11.8)

(12.8)

(29.4)

22

50

(49)

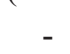

(9.8)

(32.4)

(23.5)

$$
\begin{aligned}
& - \\
& - \\
& - \\
& 31 \\
& 03 \\
& 01
\end{aligned}
$$

-
-
1
3
1

$\begin{array}{ll}- & 10\end{array}$

10
33

(9.8)

- 33

$67.4 \pm 10.6$

$66.6 \pm 11.1$

(30.4) 31

$3.8 \pm 2.3$

$120.2 \pm 8.7$

$3.4 \pm 1.9$

(1.0)

01

$67.1 \pm 10.7$

$3.7 \pm 2.2$

$136.0 \pm 15.3$

$125.6 \pm 13.6$

$76.9 \pm 7.2$

$88.6 \pm 6.1$ 
TABLE II - Distribution of controlled and uncontrolled hypertensives according to the Morisky-Green test

\begin{tabular}{|c|c|c|c|c|c|c|c|c|c|}
\hline & \multicolumn{2}{|c|}{$\begin{array}{c}\text { Controlled } \\
\mathrm{N}=67\end{array}$} & \multicolumn{2}{|c|}{$\begin{array}{l}\text { Uncontrolled } \\
\mathrm{N}=35\end{array}$} & \multicolumn{2}{|c|}{$\begin{array}{c}\text { Total } \\
\mathrm{N}=102\end{array}$} & \multirow[t]{2}{*}{$\begin{array}{l}\text { Sensitivity } \\
(\%)\end{array}$} & \multirow[t]{2}{*}{$\begin{array}{l}\text { Specificity } \\
(\%)\end{array}$} & \multirow[t]{2}{*}{$\begin{array}{c}\text { Accuracy } \\
(\%)\end{array}$} \\
\hline & $\mathrm{N}$ & $(\%)$ & $\mathrm{N}$ & $(\%)$ & $\mathrm{N}$ & $(\%)$ & & & \\
\hline \multicolumn{10}{|c|}{ Forgot to take the medicine? } \\
\hline Yes & 21 & $(20.6)$ & 19 & $(18.6)$ & 40 & $(39.2)$ & 69 & 46 & 39 \\
\hline No & $46^{*}$ & $(45.1)$ & 16 & $(15.7)$ & 62 & $(60.8)$ & & & \\
\hline \multicolumn{10}{|c|}{ Despite remembering, did not take the medicine? } \\
\hline Yes & 13 & $(12.7)$ & 04 & $(3.9)$ & 17 & $(16.7)$ & 81 & 89 & 17 \\
\hline No & 54 & $(52.9)$ & 31 & $(30.4)$ & 85 & $(83.3)$ & & & \\
\hline \multicolumn{10}{|c|}{ Stopped taking the medicine when feeling well? } \\
\hline Yes & 06 & $(5.9)$ & 03 & $(2.9)$ & 09 & $(8.8)$ & 91 & 91 & 9 \\
\hline No & 61 & $(59.8)$ & 32 & $(31.4)$ & 93 & $(91.2)$ & & & \\
\hline \multicolumn{10}{|c|}{ Stopped taking the medicine when not feeling well? } \\
\hline Yes & 04 & (3.9) & 02 & $(2.0)$ & 06 & $(5.9)$ & 67 & 34 & 66 \\
\hline No & 63 & $(61.8)$ & 33 & (32.4) & 96 & $(94.1)$ & & & \\
\hline
\end{tabular}

$* \mathrm{p} \leq 0.05$

on the patients and not only on the medication. In other words, care is taken to develop the practice of Pharmacist Attention, which considers the patient as a whole together with general and specific needs concerning the medication. Pharmacist Attention encompasses attitudes, ethical values, behaviors, ability and co-responsibility in disease prevention, promotion and recovery of health, in an integrated manner with health teams (Jaramillo et al., 2005). According to Angonesi (2008), the pharmacist must also assume a role of responsibility for the therapy (not merely acting as a subordinate to medical authorities) by promoting rational use of medications thus transforming the pharmacy into a health establishment. Therefore, training and education should be focused on critical practice and not in training a simple technician in medications. Pharmaceutical activities should be patient oriented, contributing to improvements in overall condition of health and use of medications by the Brazilian population.

Nobre, Pierin, Mion (2001) defined adherence to therapy as "level of conscience between medical prescription and patient behavior". In this context, the approach of hypertensive patients currently requires, besides technical knowledge, the perception of the socio-economic and cultural environment of the individual, such that therapeutic guidance given is congruent with their reality and achieves the treatment objectives.

According to Araújo and Garcia (2002), the variables involved in the process of adherence can be split into three groups, namely, those related to the patient, the therapeutics (costs, undesirable effects, complex treat- ment schemes and quality of life) and the health system (access to the health services, waiting time and length of consultation), plus other factors such as time in treatment and complications secondary to the disease (Gusmão, Mion, 2005; Santos et al., 2005; Araujo, Garcia, 2006). Regarding patient-related aspects, variables such as gender, age, educational level, income and marital status must be considered. Knowledge, perception and beliefs about hypertension, previous experience with the disease in the setting in which they live, their desire to learn, how to treat the disease and motivation to follow advice, combined with family and social support are all important factors to be taken into consideration in patient adherence to treatment (Jesus et al., 2008).

This study revealed that the patients took an average of 3 different medications per day (minimum 1 and maximum 12). According to Rocha et al (2008), the number of medications, the complex posology and collateral effects negatively influence the process. When prescribing pharmacological treatment, the physician should consider the frequency of doses, times of taking medicines, efficacy, undesirable adverse effects as well as the economic aspect. Whereas for non-pharmacological therapy, the ability of the patient to adapt to the new lifestyle, including regular practice of physical exercises, weight loss, changes in eating habits (i.e. cutting down intake of salt, saturated fats and sugars, since hypertensive patients are also dyslipidemic and diabetic), besides abandoning smoking and drinking habits (Farinatti et al., 2005; Gravina, Grespan, Borges, 2008). In relation 
to health services, aspects such as access, availability of a multi-disciplinary team of healthcare professionals as well as medications, frequency of consultations, health team-patient relationship, satisfaction of the individual with service, including guidance, respect, and joint decision-making are deemed pre-requisites to achieving satisfactory adherence (Coelho et al., 2005; Qureshi et al., 2007; Giorgi, 2008).

In this study, $58.8 \%$ of the patients received Enalapril Maleate as the sole medication for controlling arterial hypertension, although only $36.3 \%$ had controlled blood pressure. The remaining patients received two or more difference medicines (diuretics and/or other anti-hypertensive) for controlling the disease. According to Ribeiro (2005), the use of medication in the management of hypertension is essential, given the multifactorial characteristic of arterial hypertension, emphasizing that monotherapy using any class of medications only reduces systolic and diastolic pressures by $4 \%$ and $8 \%$ respectively, compared to baseline levels. By contrast, patients treated with a combination or association of two antihypertensives can expect reductions of $8 \%$ to $15 \%$ in blood pressure levels, that is, combining antihypertensive therapies can increase the likelihood of achieving better control of pressure and improve the $30 \%$ to $40 \%$ range of normalization under monotherapy, to levels of between $70 \%$ and $80 \%$.

A highly relevant aspect of hypertension treatment is effective pressure control allied with low incidence of side effects. In this respect, the use of several agents combined in low doses has been increasingly proposed because they enable synergic action on different causative mechanisms of arterial hypertension, without the inconvenience of adverse clinical or laboratory effects found when using higher doses of single drug (Franco et $a l ., 2005)$. Angiotensin I-converting enzyme inhibitors warrant special attention since they are effective, able to protect target organs and have a low level of collateral effects, with cephalea and cough being the most frequent side effects, i.e. they are well tolerated (Milagres, 2005). This fact partly explains why $94.1 \%$ of patients displayed a positive attitude toward using Enalapril.

Therefore, active participation in the treatment, involving correct use of medications, monitoring treatment and attending appointments, as well as changes in life style (eating habits, practicing physical activity) are considered the attributes underlying the adherence concept (Araujo, Garcia, 2006). According to Giorgi (2006), in order to attain adherence to treatment, the patient must understand their health condition, the importance of controlling blood pressure and of having access to health services, services which must be capable of providing continued treatment throughout the patient's life. The poorer the socioeconomic conditions faced by individuals, the greater the barriers to them continuing adequate treatment.

To conclude, important aspects should be observed to promote greater adherence to treatment including gender differences, proper analysis of the drug, investigation of drug interactions and associated conditions, assessment and correction of therapeutic schemes, elimination of reasons for non-control related to the prescriber and patient, search for secondary causes, personalizing of patient care, auditing of prescriptions to identify non-responsiveness of patients to a given drug and, lastly self-monitoring (Castro et al., 2006; Bakris et al., 2008; Wen-Wen et al., 2008). To this end, the services carried out by pharmacists, particularly those adopting the Pharmacist Attention concept, contribute toward adherence to pharmacological treatment (Côté et al., 2005; Castro et al., 2006).

\section{CONCLUSION}

Professional pharmacists, during their training and education, should be made aware of the importance of their active role in treating chronic diseases encompassing the rational use of medications, treatment monitoring and identifying ways of promoting improved adherence to prescribed treatment and better control of blood pressure.

\section{REFERENCES}

ANGONESI, D.; SEVALHO, G. Atenção Farmacêutica: fundamentação conceitual e crítica para um modelo brasileiro. Ciênc. Saúde Colet. Available at: <http://www. Abrasco.org.br/cienciaesaudecoletiva/artigos/artigo_int. php?id_artigo $=2884>$. Accessed on: 18 nov. 2008 .

ARAUJO, G.B.S.; GARCIA, T.R. Adesão ao tratamento antihipertensivo: uma análise conceitual. Goiânia: Rev. Eletr. Enf.,. v.8, n.2, p.259-272, 2006. Available at: <http:// www.portalbvsenf.eerp.usp.br/scielo.php?script $=$ sci arttext\&pid=S1518-19442006000200011\&lng=es\&nrm= iso\&tlng=pt $>$ Accessed on: 10 jul. 2008.

BAKRIS, G.; HILL, M.; MANCIA, G.; STEYN, K.; BLACK, H.R.; PICKERING, T.; DE GEEST, S.; RUILOPE, L.; GILES, T.D.; MORGAN, T.; KJELDSEN, S.; SHIFFRIN, E.L.; COENEN, A.; MULROW, P.; LOH, A.; MENSAH, G. Achieving blood pressure goals globally: five core actions for health-care professionals: A worldwide call to action. $J$. Hum. Hypertens., v.22, n.1, p.63-70, 2008. 
BOVET, P.; BURNIER, M.; MADELEINE, G.; WAEBER, B.; PACCAUD, F. Monitoring one-year compliance to antihypertensive medication in Seychelles. Bull. WHO, v.80, n.1., p.33-39, 2002.

BRASIL. Resolução 196 de 10 de outubro de 1996. Estabelece as diretrizes e normas regulamentadoras de pesquisas envolvendo seres humanos. Ministério da Saúde, Conselho Nacional de Saúde, MS/CNS, 10 de outubro de 1996. Available at: <http://www.conselho.saude.gov.br/ resolucoes/1996/Reso196.doc $>$. Accessed on: 12 maio 2007.

CASTRO, M.S.; CHEMELLO, C.; PILGER, D.; JUNGES, F.; BOHNEN, L.; ZIMMERMAN, L.M.; PAULINO, M.A.; JACOBS, U.; FERREIRA, M.B.C.; FUCHS, F.D. Contribuição da Atenção Farmacêutica no tratamento de pacientes hipertensos. Rev. Bras. Hipertens., v.13, n.3, p.198-202, 2006.

COELHO, E.B.; MOYSÉS, NETO, M.; PALHARES, R.; CARDOSO, M.C.M.; GELEILETE, T.J.M.; NOBRE, F. Relação entre a assiduidade às consultas ambulatoriais e o controle da pressão arterial em pacientes hipertensos. Arq. Bras. Cardiol., v.85, n.3, p.157-161, 2005.

CÔTÉ, I.; MOISAN, J.; CHABOT, I.; GRÉGOIRE, J.P. Healthrelated quality of life in hypertension: impact of a pharmacy intervention programme. J. Clin. Pharm. Ther, v.30, n.4, p.355-362, 2005.

DOSSE, C.; CESARINO, C.B.; MARTIN, J.F.V.; CASTEDO, M.C.A. Factors associated to patients noncompliance with hypertension treatment. Rev. Latino-am. Enferm., v.17, n.2, p.58-64, 2009.

FARINATTI, P.T.V.; OLIVEIRA, R.B.; PINTO, V.L.M.; MONTEIRO, W.D.; FRANCISCHETTI, E. Programa domiciliar de exercícios: efeitos de curto prazo sobre a aptidão física e pressão arterial de indivíduos hipertensos. Arq. Bras. Cardiol., v.84, n.6, p.473-479, 2006.

FRANCO, R.J.S.; RIBEIRO, J.M.; ALMEIDA, F.A.; PLAVNIK, F.L.; KOHLMAN JUNIOR, O. Estudo aberto, randomizado de avaliação de eficácia e tolerabilidade da combinação fixa de anlodipino e enalapril em uma única formulação galênica comparado à clortalidona e atenolol, no tratamento da hipertensão arterial primária estágios $1 \mathrm{e}$ 2 - subestudo do estudo EMBATES. Rev. Bras. Hipertens., v.12, suppl.1, pS25-S50, 2005.
FUCHS, S.C.; CASTRO, M.S.; FUCHS, F.C. Adesão ao tratamento anti-hipertensivo: análise das evidências. Rev. Bras. Hipertens., v.7, n.3, p.90-93, 2004.

GIL, A.C. Como elaborar projetos de pesquisa. 5.ed. São Paulo: Atlas, 2010. 160 p.

GIORGI, D.O. problema da adesão ao tratamento. Sociedade Brasileira de Hipertensão. Available at: <http://www.sbh. org.br/entrevistas/entrevista 7.htm>. Accessed on: 16 ago. 2008.

GIORGIO, D.M.A. Estratégias para melhorar a adesão ao tratamento anti-hipertensivo. Rev. Bras. Hipertens., v.13, n. 1, p.47-50, 2006

GRAVINA, C.F.; GRESPAN, S.M.; BORGES, J.L. Tratamento não-medicamentoso da hipertensão no idoso. Rev. Bras. Hipertens., v.14, n.1, p.33-36, 2007.

GU, D.; REYNOLDS, K.; WU, X.; CHEN, J.; DUAN, X.; MUNTNER, P.; HUANG, G.; REYNOLDS, R.F.; SU, S.; WHELTON, P.K.; HE, J. Prevalence, awareness, treatment, and control of hypertension in China. Hypertension, v.40, n.6, p.920-927, 2002.

GUSMÃO, J.L.; MION JR, D. Adesão ao tratamento: Conceitos. Rev. Bras. Hipertens., v.13, n.1, p.23-25, 2006.

HAIR, J.F.; ANDERSON, R.E.; TATHAM, R.L.; BLACK, W.C. Análise multivariada de dados. 5.ed. Porto Alegre: Bookman, 2005. 600 p.

JESUS, E.S.; AUGUSTO, M.A.O.; GUSMÃO, J.; MION JR, D.; ORTEGA, K.; PIERIN, A.M.G. Perfil de um grupo de hipertensos: aspectos biossociais, conhecimentos e adesão ao tratamento. Acta Paul. Enferm., v.21, n.1, p.56-65, 2008.

JARAMILLO, N.M.; IVAMA, A.M.; BARBANO, D.B.; SANTOS, M.R.; LUIZA, V.L. Avaliação da Assistência farmacêutica no Brasil. Estrutura, processos e resultados. Brasília: OPAS/ OMS/MS, 2005. 260 p.

JO, I.; AHN, Y.; LEE, J.; SHIN, K.R.; LEE, H.K.; SHIN, C. Prevalence, awareness, treatment, control and risk factors of hypertension in Korea: the Asian study. J. Hypertens., v.19, n.9, p.1523-1532, 2001.

KHALIL, S.A.; ELZUBIER, A.G. Drug compliance among hypertensive patient in Tabuk, Saudi Arabia. J. Hypertens., v.15, n.5, p.561-565, 1997. 
LESSA, I. Impacto social da não-adesão ao tratamento da hipertensão arterial. Rev. Bras. Hipertens., v.13, n.1. p.3946, 2006.

LEWINGTON, S.; CLARKE, R.; QIZILBASH, N.; PETO, R.; COLLINS, R. Age-specific relevance of usual blood pressure to vascular mortality: a meta-analysis of individual data for one million adults in 61 prospective studies. Lancet, v.360, n.9349, p.1903-1913, 2003.

LIEBERMAN, A. Aspectos epidemiológicos e o impacto clínico da hipertensão no indivíduo idoso. Rev. Bras. Hipertens., v.14, n.1, p.17-20, 2007.

LOTUFO, P.A. Stroke in Brazil: a neglected disease. São Paulo Med. J., v.123, n.1, p.3-4, 2005.

MARTINO, M.D.; VERONESI, C.; ESPOSITI, L.D.; SCARPA, F.; BUDA, S.; DIDONI, G.; PETRACCI, E.; VALPIANI, G.; EAPOSITI, E.D. Adherence to antihypertensive drug treatment and blood pressure control: a real practice analysis in Italy. J. Hum. Hypert., v.22, n.1, p.51-53, 2008.

MILAGRES, R.; UEHARA, M.H.; ZANELLA, M.T.; PLAVNIK, F.L.; KOHLMAN Jr, O. Estudo aberto, randomizado, comparativo da combinação fixa de anlodipino e enalapril em uma única formulação galênica versus anlodipino e enalapril isoladamente em pacientes hipertensos primários estágio 1 e 2 e diabéticos tipo 2 subestudo do estudo EMBATES. Rev. Bras. Hipertens., v.12, suppl.1, p.S32-S41, 2005.

MONEGO, E.T.; JARDIM, P.C.B.V. Determinantes de risco para doenças cardiovasculares em escolares. Arq. Bras. Cardiol, v.87, n.1, p.37-45, 2006.

MORISKY, D.E.; GREEN, L.W.; LEVINE, D.M. Concurrent and predictive validity of a self-reported measure of medication adherence. Med. Care, v.24, n.1, p.67-74, 1986.

NOBRE, F.; PIERIN, A.M.G.; MION JR., D. Adesão ao tratamento: o grande desafio da hipertensão. 1.ed. São Paulo: Lemos Editorial, 2001. 130 p.

OLIVEIRA, F.A.; REIS, M.A.; CASTRO, E.C.C; CUNHA, S.F.C.; TEIXEIRA, V.P.A. Doenças infecciosas como causas de morte em idosos autopsiados. Rev. Soc. Bras. Med. Trop., v.37, n.1, p.33-36, 2004.
OMRAM, A.R. The epidemiologic transition: a theory of the epidemiology of population change. Milbank Mem. Fund. Q. Health Soc., v.49, n.4, p.509-538, 1971.

PASSOS, V.M.A.; ASSIS, T.D.; BARRETO, S.M. Hipertensão arterial no Brasil: a estimativa de prevalência a partir de estudos de base populacional. Epidemiol. Serv. Saúde, v.15, n.1, p.35-45, 2006.

PÉREZ, A.M.G.; FERNÁNDEZ, L.F.; CRESPO, F.M.; RUIZ, A.J.G.; PRADOS, D.T.; DE LA CUESTA, S.; ALARCÓN, F. Cómo diagnosticar el cumplimiento terapéutico en atención primaria? Medicina de Família (And), v.1, n.1, p.13-19, 2000. Available at: <http://www.sanfyc.es/Revista/ PDF/numero\%201/013-19.pdf>. Accessed on: 09 dec. 2008.

PESTANA, M.H.; GAGEIRO, J.N. Análise de dados para ciências sociais: a complementaridade do SPSS. 5.ed. Lisboa: Edições Silabo, 2008. 694 p.

QURESHI, N.N.; HATCHER, J.; CHATURVEDI, N.; JAFAR, T.H. and Hypertension Research Group. Effect of general practitioner education on adherence to antihypertensive drugs: cluster randomized controlled trial. London: $B M J$, 2007; Available at: <http://bmj.com/cgi/content/full/335/7 628/1030\#otherarticles> Accessed on: 2 jun. 2008.

RIBEIRO, A.B. Associações fixas de antihipertensivos: a nova tendência. Rev. Bras. Hipertens, v.12, suppl.1, p.S5-S6, 2005.

ROCHA, C.H.; OLIVEIRA, A.P.S.; FERREIRA, C.; FAGGIANI, F.T.; SCHROETER, G.; SOUZA, A.C.A. DECARLI, G.A.; MORRONE, F.B.; WERLANG, M.C. Adesão à prescrição médica em idosos de Porto Alegre, RS. Ciênc. Saúde Colet., v.13, suppl.1, p.703-710., 2008.

SANTOS, Z.M.S.A.; FROTA, M.A.; CRUZ, D.M.; HOLANDA, S.D.O. Adesão do cliente hipertenso ao tratamento: Análise com abordagem interdisciplinar. Texto Contexto Enferm., v.14, n.3, p.332-340, 2005.

STEIN, A.D.; STOYANOVSKY, V.; MINCHEVA, V.; DIMITROV, E.; HODJEVA, D.; PETKOV, A.; TSANOVA, V. Prevalence, awareness, treatment and control of hypertension in a working Bulgarian population. Eur. J. Epidemiol., v.16, n.3, p.265-270, 2000. 
STRELEC, M.A.A.M.; PIERIN, A.M.G.; Mion JR, D. A influência do conhecimento sobre a doença e a atitude frente à tomada dos remédios no controle da hipertensão arterial. Arq. Bras. Cardiol., v.81, n.4, p.343-348, 2003.

\section{DIRETRIZES BRASILEIRAS DE HIPERTENSÃO} ARTERIAL. Sociedade Brasileira de Cardiologia, Sociedade Brasileira de Hipertensão, Sociedade Brasileira de Nefrologia. Rio de Janeiro: Arq. Bras. Cardiol., v.89, n.3, p.24-79, 2007. Available at: <http://www.arquivosonline. com.br/2007/8903/pdf/8903012.pdf $>$ Accessed on: 20 may 2008 .

VRIJENS, B.; VINCZE, G.; KRISTANTO, P.; URQUHART, J.; BURNIER, M. Adherence to prescribed antihypertensive drug treatments: longitudinal study of electronically compiled dosing histories. BMJ, v.336, p.1114-1117, 2008. Available at: <http://bmj.com/cgi/content/ full/336/7653/1114> Accessed on: 2 jun. 2008
WEN-WEN, L.; WALLAGEN, M.I.; FROELICHER, E.S. Hypertension control, predictors for medication adherence and gender differences in older Chinese immigrants. J. Adv. Nurs., v.61, n.3, p.326-335, 2008.

WETZELS, E.C.G.; NELEMANS, P.; SCHOUTEN, J.; PRINS, H.M. Facts and fiction of poor compliance as a cause of inadequate blood pressure control: a systematic review. $J$. Hypertens., v.22, n.10, p.1849-1855, 2004.

Received for publication on $17^{\text {th }}$ December 2008 Accepted for publication on $10^{\text {th }}$ March 2010 